\title{
Effects of gamma radiation on physicochemical, thermogravimetric, microstructural and microbiological properties during storage of apple pomace flour
}

\author{
Vivian Cristina Ito a, *, Acácio Antonio Ferreira Zielinski a , Suelen Avila ${ }^{\mathrm{b}}$, Marta Spoto ${ }^{\mathrm{c}}$, \\ Alessandro Nogueira ${ }^{a}$, Egon Schnitzler ${ }^{a}$, Luiz Gustavo Lacerda ${ }^{a}$ \\ a Post Graduate Program in Food Science and Technology, State University of Ponta Grossa (UEPG), Av. Carlos Cavalcanti 4748 Uvaranas Campus, CEP \\ 84.030-900, Ponta Grossa, PR, Brazil \\ b Post Graduate Program in Food Engineering, Federal University of Paraná (UFPR), Av. Cel. Francisco Heráclito dos Santos 210 Polytechnic Centre, \\ 81531-980, Curitiba, PR, Brazil \\ ${ }^{c}$ Centre for Nuclear Energy in Agriculture, State University of São Paulo (USP), Av. Centenário, 303, Luiz de Queiroz Campus, 13900-470, Piracicaba, Brazil
}

\section{A R T I C L E I N F O}

Article history:

Received 3 May 2016

Received in revised form

24 November 2016

Accepted 11 December 2016

Available online 19 December 2016

\section{Keywords:}

Gamma radiation

Apple pomace

Dietary fibre

Stability

Hierarchical cluster analysis

\begin{abstract}
A B S T R A C T
The effects of gamma radiation on the physicochemical, thermogravimetric, microstructural and microbiological properties of apple pomace flour were evaluated for a period of nine months storage. Calcium levels were higher in the irradiated samples. The irradiated samples remained stable during storage regarding the contents of protein, lipids, total dietary fibre, total reducing sugars, potassium, zinc, iron and manganese. The chemometric approach enabled a better visualisation of the samples. The results were not influenced by the effect of gamma radiation during storage. The thermogravimetric curves showed four major mass losses in consecutive reactions. The photomicrographs showed a composite of organic and heterogeneous material, with agglomerated particles with irregular shapes and sizes. For the microbiological analysis at a dose of $1 \mathrm{kGy}$, the presence of moulds occurred at 9 months of storage, however, the levels were below the indicative tolerance and for $2 \mathrm{kGy}$ there was no contamination of yeasts and moulds.
\end{abstract}

(C) 2016 Elsevier Ltd. All rights reserved.

\section{Introduction}

It is estimated that $70 \%$ of apples are consumed in a fresh state, while $30 \%$ are used in the processing of juices, ciders, wines, vinegar, spirits and other products derived from this fruit (Alberti et al., 2016). With this industrialisation has resulted in a subsequent increase in production and marketing that produces an enormous volume of waste in many countries - about 12 million tonnes per year (USDA, 2015).

The composition of the nutrients of apple pomace is associated with the characteristics of the fruit processing and also the methodology used to extract the juice, contains high levels of carbohydrates, fibre and phenolic compounds (Ito, Avila, \& Wosiacki, 2015).

\footnotetext{
* Corresponding author.

E-mail addresses: vivianito@gmail.com (V.C. Ito), aczielinski@gmail.com (A.A. Ferreira Zielinski), suelenavila@gmail.com (S. Avila), martaspoto@usp.br (M. Spoto), alessandronog@yahoo.com.br (A. Nogueira), egons@uepg.br (E. Schnitzler), lglacerda@uepg.br (L.G. Lacerda).
}

The high fibre content found in apple pomace can aid in the prevention and treatment of obesity, arteriosclerosis, cardiovascular disease, colon cancer and diabetes. The consumption of dietary fibre decreases insulin levels in the blood and brings benefits to the gastro-intestinal tract (Kosmala, Kolodziejczyk, Zduńczyk, Juśkiewicz, \& Boros, 2011). These health-promoting properties have been the subject of research studies related to apples and their derivatives (Yan \& Kerr, 2013). However, it is still rare to find thermal behaviour studies of these fibres using thermogravimetry and it is very important to reveal all the relevant details, such as the thermal stability and decomposition profile of the raw material.

Food irradiation is a technology that aims to improve food security. In recent decades it has been widely researched and its effects are known to preserve, reduce microbial load or sterilization, increase the shelf life of products and above all to maintain the quality of food (Tawema, Han, Vu, Salmieri, \& Lacroix, 2016). It represents an effective and environmentally friendly technology (Pereira et al., 2014). Its efficacy and safety are proven (Food and Agricultural Organization (FAO); International Atomic Energy 
Agency (IAEA); World Health Organization (WHO)). However, the aim of this study was to evaluate the physicochemical, thermogravimetric, microstructural and microbiological properties of apple pomace flour irradiated with doses of 0,1 and $2 \mathrm{kGy}$, during $0,3,6$ and 9 months of storage.

\section{Materials and methods}

\subsection{Materials}

The Fuji apples used in the experiments were purchased in the local supermarket at commercial maturity in the city of Ponta Grossa ( $25^{\circ} 05^{\prime} 42^{\prime \prime}$ S 50 09' 43" O), Paraná, Brazil, from the 2013 harvest.

\subsection{Processing of apple pomace}

The pomace was obtained according to the methodology used by Ito et al. (2016). The flour was separated and packed in samples of about $250 \mathrm{~g}$ in small non-toxic polyethylene bags with hermetic closure until the moment of the analysis.

\subsection{Radiation of samples}

All the samples of the apple pomace flour were subjected to gamma radiation at doses of 0,1 and $2 \mathrm{kGy}$ at $0.87 \mathrm{kGy} / \mathrm{h}$ dose rate. Harwell Amber 3042 dosimeters were used to measure the radiation dose and the uncertainty dose was less than $1 \%$. The irradiation source was with Cobalt 60 (Gammacell Excell 220 - MDS Nordion) located in the Centre for Nuclear Energy in Agriculture (CENA/USP). The pomace was evaluated during $0,3,6$ and 9 months after irradiation. The sample with $0 \mathrm{kGy}$ dose (control), 1 and $2 \mathrm{kGy}$ were subjected to the analysis (time 0 ), and the others samples were stored at room temperature until the end of each storage time (Ito et al., 2016).

\subsection{Physicochemical analysis}

The contents of moisture, protein, ash, lipids and total dietary fibre of the apple pomace flour (APF) samples were determined according to the official methods (AOAC, 2005). Total reducing sugars content was determined using the Somogyi Nelson method (Somogyi, 1952). The determination of pectin, was performed according to the methodology proposed by Fertonani et al. (2009). For the analysis of calcium (Ca), copper (Cu), cobalt (Co), iron (Fe), magnesium $(\mathrm{Mg})$, potassium $(\mathrm{K})$, sodium $(\mathrm{Na})$, zinc $(\mathrm{Zn})$ and manganese $(\mathrm{Mn})$ the readings were taken using a flame atomic absorbtion spectrometer (Varian, model 240FS), using as an accessory an automatic SIPS diluter system equipped with deuterium lamp as background correction and multi-element hollow cathode lamps. The results were performed in triplicate and expressed in $\mathrm{g} .100 \mathrm{~g}^{-1}$ dry matter $(\mathrm{DM})$. The water activity $\left(\mathrm{A}_{\mathrm{w}}\right)$ was measured with a digital $A_{w}$ meter (Aqualab ${ }^{\circledR}$, USA).

\subsection{Thermal properties: thermogravimetry (TG) and thermal differential analysis (DTA)}

To obtain the TG and DTA results, TGA-50 (Shimadzu, Japan) equipment was used. Approximately $7.0 \mathrm{mg}$ of each sample was placed in open micro alpha-alumina $\left(\alpha-\mathrm{Al}_{2} \mathrm{O}_{3}\right)$ pans that were preweighed on thermobalance equipment. Readings were performed in a synthetic air atmosphere at a flow rate of $100 \mathrm{ml} \mathrm{min}^{-1}$, with a

Table 1

Effects of gamma irradiation on the physicochemical properties in APF during storage.

\begin{tabular}{|c|c|c|c|c|c|}
\hline \multirow[t]{2}{*}{ Analysis (g $100 \mathrm{~g}^{-1}$ ) } & \multirow[t]{2}{*}{ Doses (kGy) } & \multicolumn{4}{|l|}{ Time (months) } \\
\hline & & 0 & 3 & 6 & 9 \\
\hline \multirow[t]{3}{*}{ Moisture } & 0 & $5.66 \pm 0.04^{\mathrm{d}}$ & $7.87 \pm 0.51^{\mathrm{ABC}}$ & $9.59 \pm 0.38^{b}$ & $11.52 \pm 0.76^{\mathrm{a}}$ \\
\hline & 1 & $5.53 \pm 0.25^{\mathrm{d}}$ & $6.75 \pm 0.44^{\mathrm{Bc}}$ & $8.52 \pm 1.00^{\mathrm{b}}$ & $11.50 \pm 0.17^{\mathrm{a}}$ \\
\hline & 2 & $5.87 \pm 0.05^{c}$ & $8.46 \pm 0.66^{\mathrm{Ab}}$ & $9.37 \pm 0.73^{b}$ & $11.82 \pm 0.25^{\mathrm{a}}$ \\
\hline \multirow[t]{3}{*}{ Protein } & 0 & $4.49 \pm 0.05^{\mathrm{Aa}}$ & $3.05 \pm 0.01^{\mathrm{Bb}}$ & $3.68 \pm 0.55^{\mathrm{b}}$ & $3.42 \pm 0.65^{\mathrm{b}}$ \\
\hline & 1 & $3.90 \pm 0.58^{\mathrm{AB}}$ & $4.00 \pm 0.37^{\mathrm{A}}$ & $3.77 \pm 0.31$ & $3.54 \pm 0.40$ \\
\hline & 2 & $3.42 \pm 0.19^{\mathrm{B}}$ & $3.59 \pm 0.06^{\mathrm{A}}$ & $4.15 \pm 0.56$ & $3.85 \pm 0.49$ \\
\hline \multirow[t]{3}{*}{ Lipids } & 0 & $1.96 \pm 0.15$ & $1.95 \pm 0.40$ & $1.84 \pm 0.47$ & $1.73 \pm 0.42$ \\
\hline & 1 & $1.75 \pm 0.13$ & $1.64 \pm 0.48$ & $1.63 \pm 0.47$ & $1.67 \pm 0.19$ \\
\hline & 2 & $1.90 \pm 0.12$ & $1.97 \pm 0.05$ & $1.78 \pm 0.26$ & $1.75 \pm 0.31$ \\
\hline \multirow[t]{3}{*}{ Total Reducing Sugars } & 0 & $37.60 \pm 0.50^{\mathrm{AB}}$ & $37.54 \pm 0.50$ & $37.79 \pm 0.17$ & $37.53 \pm 0.55$ \\
\hline & 1 & $37.23 \pm 0.77^{\mathrm{B}}$ & $38.00 \pm 0.79$ & $38.06 \pm 0.44$ & $37.34 \pm 0.51$ \\
\hline & 2 & $38.36 \pm 0.04^{\mathrm{A}}$ & $37.66 \pm 1.25$ & $38.35 \pm 0.27$ & $37.96 \pm 0.05$ \\
\hline \multirow[t]{3}{*}{ Reducing Sugars } & 0 & $27.36 \pm 0.27^{\mathrm{a}}$ & $26.50 \pm 0.47^{b}$ & $26.80 \pm 0.14^{\mathrm{ab}}$ & $26.56 \pm 0.31^{b}$ \\
\hline & 1 & $26.61 \pm 1.01$ & $26.71 \pm 0.57$ & $26.62 \pm 0.50$ & $26.68 \pm 0.48$ \\
\hline & 2 & $27.59 \pm 0.42^{\mathrm{a}}$ & $26.65 \pm 0.44^{\mathrm{b}}$ & $26.89 \pm 0.62^{\mathrm{ab}}$ & $26.46 \pm 0.40^{b}$ \\
\hline \multirow[t]{3}{*}{ Glucose - GOD } & 0 & $7.82 \pm 0.22^{\mathrm{a}}$ & $6.73 \pm 0.43^{\mathrm{ABb}}$ & $6.88 \pm 0.41^{\mathrm{ABb}}$ & $6.56 \pm 0.57^{\mathrm{Bb}}$ \\
\hline & 1 & $7.86 \pm 0.17^{\mathrm{a}}$ & $6.52 \pm 0.05^{\mathrm{Bb}}$ & $6.47 \pm 0.14^{\mathrm{Bb}}$ & $6.34 \pm 0.29^{\mathrm{Bb}}$ \\
\hline & 2 & $8.02 \pm 0.00^{\mathrm{a}}$ & $7.16 \pm 0.10^{\mathrm{Ac}}$ & $7.35 \pm 0.09^{\mathrm{Abc}}$ & $7.42 \pm 0.16^{\mathrm{Ab}}$ \\
\hline \multirow[t]{3}{*}{ Sucrose } & 0 & $10.24 \pm 0.61$ & $11.04 \pm 0.54$ & $10.99 \pm 0.24$ & $10.97 \pm 0.36$ \\
\hline & 1 & $10.61 \pm 0.31$ & $11.29 \pm 1.36$ & $11.44 \pm 0.18$ & $10.67 \pm 0.59$ \\
\hline & 2 & $10.77 \pm 0.41$ & $11.01 \pm 0.88$ & $11.46 \pm 0.57$ & $11.50 \pm 0.45$ \\
\hline \multirow[t]{3}{*}{ Fructose } & 0 & $19.54 \pm 0.48$ & $19.77 \pm 0.82$ & $19.92 \pm 0.38$ & $20.00 \pm 0.87$ \\
\hline & 1 & $18.75 \pm 1.18$ & $20.19 \pm 0.56$ & $20.15 \pm 0.64$ & $20.34 \pm 0.74$ \\
\hline & 2 & $19.57 \pm 0.42$ & $19.49 \pm 0.35$ & $19.55 \pm 0.65$ & $19.04 \pm 0.54$ \\
\hline \multirow[t]{3}{*}{ Total Dietary Fibre } & 0 & $50.01 \pm 1.47^{\mathrm{Aa}}$ & $49.30 \pm 0.55^{a}$ & $47.27 \pm 1.18^{\mathrm{b}}$ & $47.27 \pm 0.45^{\mathrm{b}}$ \\
\hline & 1 & $46.05 \pm 1.38^{\mathrm{B}}$ & $46.05 \pm 1.61$ & $46.65 \pm 0.36$ & $45.98 \pm 0.56$ \\
\hline & 2 & $45.46 \pm 1.15^{\mathrm{B}}$ & $45.46 \pm 1.75$ & $46.25 \pm 0.24$ & $46.26 \pm 0.58$ \\
\hline \multirow[t]{3}{*}{ Pectin } & 0 & $14.15 \pm 0.07^{\mathrm{a}}$ & $14.16 \pm 1.17^{\mathrm{a}}$ & $12.27 \pm 0.30^{\mathrm{b}}$ & $12.04 \pm 0.21^{b}$ \\
\hline & 1 & $14.33 \pm 1.02^{\mathrm{a}}$ & $14.47 \pm 0.56^{\mathrm{a}}$ & $12.44 \pm 0.29^{b}$ & $12.13 \pm 0.48^{b}$ \\
\hline & 2 & $14.59 \pm 0.71^{\mathrm{a}}$ & $14.53 \pm 0.81^{\mathrm{a}}$ & $11.84 \pm 0.34^{\mathrm{b}}$ & $11.51 \pm 0.58^{\mathrm{b}}$ \\
\hline
\end{tabular}

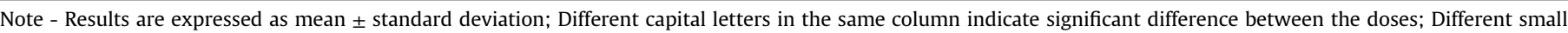
letters in the same line indicate significant differences during storage. The significant differences at a level of $5 \%$ were performed by Duncan's test. 
heating rate of $10{ }^{\circ} \mathrm{C} \mathrm{min}^{-1}$ from an initial temperature of $10{ }^{\circ} \mathrm{C}$ to a final temperature of $600{ }^{\circ} \mathrm{C}$. All mass loss percentages were determined by TA- 60 WS data analysis software. The analyses were performed in the first and last stages of the research.

\subsection{Scanning electron microscopy - SEM}

The samples were fixed in the sample holder and were subjected to a plating technique (SHIMADZU IC - ION COATER 50) where the samples were covered with a thin layer of gold in a vacuum environment, for $5 \mathrm{~min}$. After this preparation, the microanalysis data were collected in a scanning electron microscope (Shimadzu - SSX 550). The analyses were performed in the first and last stages of the research. Magnifications of $100 \times$ were used.

\subsection{Microbiological analysis}

In order to evaluate the microbiological quality of the APF, the following analyses were performed: thermotolerant coliforms, salmonella, moulds and yeasts, according to the National Health Surveillance Agency, Collegiate Board Resolution no.12 (ANVISA, 2001). This resolution establishes the sanitary microbiological standards for foods but there are no specific standards for apple

Table 2

Effects of gamma irradiation on minerals in APF during storage.

\begin{tabular}{|c|c|c|c|c|c|}
\hline \multirow[t]{2}{*}{ Minerals } & \multirow[t]{2}{*}{ Doses (kGy) } & \multicolumn{4}{|l|}{ Time (months) } \\
\hline & & 0 & 3 & 6 & 9 \\
\hline \multirow[t]{3}{*}{ Ash $\left(\mathrm{g} 100 \mathrm{~g}^{-1}\right)$} & 0 & $1.78 \pm 0.07$ & $1.51 \pm 0.11$ & $1.51 \pm 0.30$ & $1.69 \pm 0.08$ \\
\hline & 1 & $1.65 \pm 0.10^{\mathrm{ab}}$ & $1.63 \pm 0.13^{\mathrm{b}}$ & $1.83 \pm 0.12^{\mathrm{a}}$ & $1.76 \pm 0.01^{\mathrm{ab}}$ \\
\hline & 2 & $1.67 \pm 0.09$ & $1.63 \pm 0.12$ & $1.74 \pm 0.20$ & $1.71 \pm 0.03$ \\
\hline \multirow[t]{3}{*}{ Potassium (mg $100 \mathrm{~g}^{-1}$ ) } & 0 & $242.73 \pm 2.18^{\mathrm{Aa}}$ & $231.62 \pm 3.42^{\mathrm{ABb}}$ & $236.63 \pm 4.43^{\text {Aab }}$ & $222.52 \pm 3.28^{\mathrm{Bc}}$ \\
\hline & 1 & $238.04 \pm 2.05^{\mathrm{Ab}}$ & $240.05 \pm 3.07^{\mathrm{Aab}}$ & $242.73 \pm 4.08^{\mathrm{Aa}}$ & $238.67 \pm 3.51^{\mathrm{Aab}}$ \\
\hline & 2 & $227.49 \pm 1.65^{\mathrm{B}}$ & $227.19 \pm 3.05^{\mathrm{B}}$ & $228.86 \pm 3.34^{\mathrm{B}}$ & $225.66 \pm 5.17^{\mathrm{B}}$ \\
\hline \multirow[t]{3}{*}{ Zinc (mg $100 \mathrm{~g}^{-1}$ ) } & 0 & $1.44 \pm 0.36^{\mathrm{A}}$ & $1.22 \pm 0.46$ & $0.96 \pm 0.15^{\mathrm{A}}$ & $1.12 \pm 0.02$ \\
\hline & 1 & $1.03 \pm 0.13^{\mathrm{AB}}$ & $1.01 \pm 0.20$ & $1.04 \pm 0.18^{A}$ & $0.93 \pm 0.06$ \\
\hline & 2 & $0.78 \pm 014^{\mathrm{B}}$ & $0.78 \pm 0.11$ & $0.79 \pm 0.09^{\mathrm{B}}$ & $0.76 \pm 0.05$ \\
\hline \multirow[t]{3}{*}{ Iron (mg $\left.100 \mathrm{~g}^{-1}\right)$} & 0 & $3.33 \pm 0.09^{\mathrm{A}}$ & $3.13 \pm 0.17^{\mathrm{A}}$ & $3.19 \pm 0.13^{\mathrm{A}}$ & $3.10 \pm 0.06^{\mathrm{A}}$ \\
\hline & 1 & $1.77 \pm 0.01^{\mathrm{B}}$ & $1.33 \pm 0.34^{\mathrm{B}}$ & $1.63 \pm 0.01^{\mathrm{B}}$ & $1.70 \pm 0.02^{\mathrm{B}}$ \\
\hline & 2 & $1.91 \pm 0.41^{\mathrm{B}}$ & $1.81 \pm 0.27^{\mathrm{B}}$ & $1.87 \pm 0.42^{\mathrm{B}}$ & $1.91 \pm 0.41^{\mathrm{AB}}$ \\
\hline \multirow[t]{3}{*}{ Calcium (mg $100 \mathrm{~g}^{-1}$ ) } & 0 & $76.00 \pm 1.60^{C}$ & $76.67 \pm 1.51^{\mathrm{C}}$ & $74.77 \pm 1.00^{\mathrm{C}}$ & $74.13 \pm 1.00^{C}$ \\
\hline & 1 & $107.55 \pm 1.67^{\mathrm{Ab}}$ & $116.58 \pm 1.40^{\mathrm{Aa}}$ & $117.65 \pm 2.81^{\mathrm{Aa}}$ & $117.35 \pm 2.04^{\mathrm{Aa}}$ \\
\hline & 2 & $84.13 \pm 2.61^{\mathrm{Bb}}$ & $105.22 \pm 3.00^{\mathrm{Ba}}$ & $102.22 \pm 1.96^{\mathrm{Ba}}$ & $102.86 \pm 2.53^{\mathrm{Ba}}$ \\
\hline \multirow[t]{3}{*}{ Manganese (mg $100 \mathrm{~g}^{-1}$ ) } & 0 & $0.69 \pm 0.15$ & $0.69 \pm 0.13$ & $0.72 \pm 0.13$ & $0.70 \pm 0.14$ \\
\hline & 1 & $0.76 \pm 0.12$ & $0.71 \pm 0.10$ & $0.76 \pm 0.12$ & $0.71 \pm 0.11$ \\
\hline & 2 & $0.63 \pm 0.16$ & $0.51 \pm 0.11$ & $0.56 \pm 0.07$ & $0.57 \pm 0.06$ \\
\hline \multirow[t]{3}{*}{ Magnesium (mg $100 \mathrm{~g}^{-1}$ ) } & 0 & $92.84 \pm 2.02^{\mathrm{ABa}}$ & $83.21 \pm 2.72^{\mathrm{Ab}}$ & $83.77 \pm 1.57^{\mathrm{Ab}}$ & $75.23 \pm 1.00^{\mathrm{Ac}}$ \\
\hline & 1 & $99.80 \pm 1.00^{\mathrm{Aa}}$ & $64.42 \pm 2.00^{\mathrm{Cc}}$ & $70.67 \pm 1.00^{\mathrm{Bb}}$ & $64.32 \pm 0.99^{\mathrm{BC}}$ \\
\hline & 2 & $89.93 \pm 2.30^{\mathrm{Ba}}$ & $77.67 \pm 1.00^{\mathrm{Bb}}$ & $77.60 \pm 1.00^{\mathrm{ABb}}$ & $76.00 \pm 2.00^{\mathrm{Ab}}$ \\
\hline
\end{tabular}

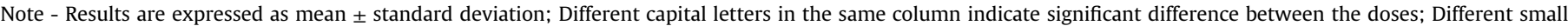
letters in the same line indicate significant differences during storage. The significant differences at a level of $5 \%$ were performed by Duncan's test.

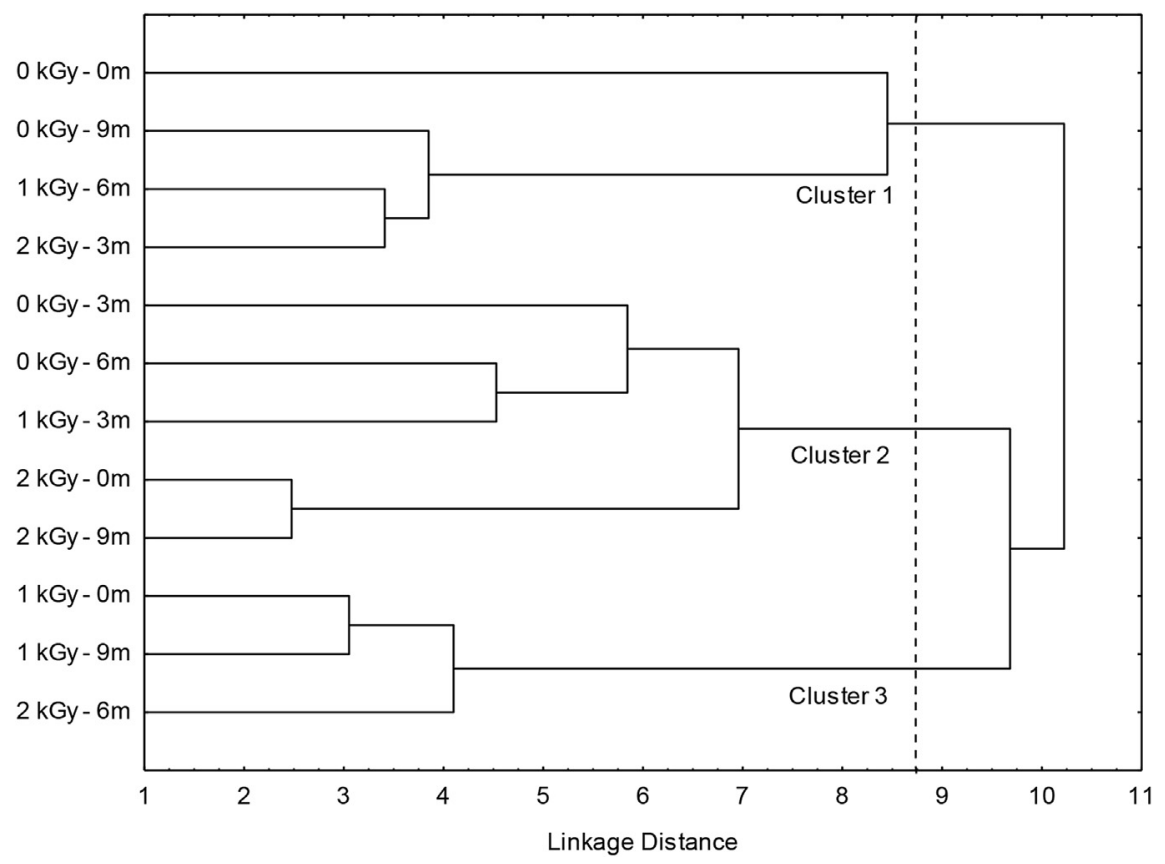

Fig. 1. Hierarchical Cluster Analysis (HCA) of the physicochemical characteristics applied in APF during storage. 
pomace flour. In this study the samples were included in the food group assigned to "dehydrated fruit products" with a maximum tolerance for an indicative sample being $10^{2} \mathrm{NMP} \mathrm{g}^{-1}$ or CFU g ${ }^{-1}$ of thermotolerant coliform and absence of Salmonella sp. $25 \mathrm{~g}$. The analyses of moulds and yeasts are not required for "dried fruit products." However, to explore the effects of radiation, these analyses were investigated for tolerance where the sample was indicative of $10^{4} \mathrm{CFU} \mathrm{g}{ }^{-1}$. The identification of possible fungi present in the samples was performed by slide preparation, which was obtained from the plates used for the mould and yeast counts. The slides were stained with acid fuchsin and the structure of the mould was evaluated under a microscope (OLYMPUS BX40 with Pm-10AK3 Olympus system photomicrography). The analyses were performed in triplicate during the first and last stages of the research.

\subsection{Statistical analysis}

The data were presented as mean \pm standard deviation and the means were compared by Duncan's test $(p<0.05)$. A chemometric approach consisting of hierarchical cluster analysis (HCA) was used for the physicochemical analysis. All the results were previously autoscaled to standardise the statistical significance for all the variables. For the HCA, the similarities of the samples and the variables were calculated based on the Euclidean distance, and the hierarchical agglomerative Ward method was used to cluster the samples. In order to compare the results between the clusters that were formed, Levene's test was performed to verify the homogeneity of variance, while one-way analysis of variance (ANOVA) and Fisher's LSD test were then used to identify the differences between the clusters. The Kruskal-Wallis was used to compare the variables with non-parametric data ( $p<0.05$ ) (Zielinski et al., 2014). All statistical analysis was performed using STATISTICA 7.0 software (Stat-Soft Inc., Tulsa, OK, USA).

\section{Results and discussion}

\subsection{Effects of gamma radiation on physicochemical properties during storage: using multivariate techniques}

The results of the physicochemical analysis (Table 1 ), sample control (0 kGy - 0 months), were similar to studies using dehydrated apple pomace (Dhillon, Kaur, Brar, \& Verma, 2012; Fertonani et al., 2009). In terms of moisture analysis, it is possible to verify that irradiation did not influence the level, only the period in which it was stored. This can be associated with the hygroscopic character of flours and their consequent tendency to respond to changes in ambient relative humidity, as well as the transfer properties of water vapour of the packaging material.

The levels of total reducing sugars and glucose were higher after radiation at the dose of $2 \mathrm{kGy}$, whereas the protein and total dietary fibre levels were reduced at both doses 1 and $2 \mathrm{kGy}$. Whereas, the other physicochemical properties such as lipids, sucrose and fructose were remained at the same level after radiation as well as during storage. The gamma radiation did not influence the concentration of pectin ( $p>0.05)$, but during a 6 month period there was a significant loss $(\mathrm{p}<0.05)$ in all the samples (Table 1$)$.

According to Pirmohammadi, Rouzbehan, Rezayazdi, and Zahedifar (2006), some characteristics directly influence the nutritive value of apple pomace to make it a very heterogeneous material, such as the type of cultivar used for processing agricultural practices and fruit ripening, and the juice extraction methodology. Fibres are considered to be the most relevant phytochemical raw material in apple pomace: as well as being found in large quantities, they also allow different applications (Ito et al., 2015).

Oliveira, Silva, Nogueira, and Wosiacki (2006) reported that the mineral content in pressed apple pomace is low, which is due to the processing of fruits, causing leaching of minerals for juice, appleproduct, giving quality to this drink. Table 2 presents the mineral content found in the apple pomace flour.

The levels of zinc and iron remained stable during storage; the control sample had higher levels than the irradiated samples $(\mathrm{p}<0.05)$. In assessing the mineral levels in dehydrated apple pomace, Dhillon et al. (2012) found in their study $1.50 \mathrm{mg} 100 \mathrm{~g}^{-1}$ for zinc and $3.18-3.83 \mathrm{mg} 100 \mathrm{~g}^{-1}$ for iron. The levels of calcium in the irradiated samples were significantly higher $(p<0.05)$ when compared to the control sample. Manganese levels were stable during storage and the contents were similar in all the samples. The magnesium levels in the irradiated samples and shelf life were significantly different ( $\mathrm{p}<0.05$ ).

Potassium is found in higher concentrations in apple pomace (Dhillon et al., 2012). This is due to the heavy mineral fertilisation of apple orchards, because mineral deficiency in the soil results in small fruits with low acid content and less intense red colour at harvest (Hunsche, Brackmann, \& Ernani, 2003). In the present

Table 3

Results (mean) of the physicochemical analysis suggested by the Hierarchical Cluster Analysis (HCA).

\begin{tabular}{|c|c|c|c|c|c|c|}
\hline Variables & $\begin{array}{l}\text { Cluster } 1 \\
\mathrm{n}=4\end{array}$ & $\begin{array}{l}\text { Cluster } 2 \\
\mathrm{n}=5\end{array}$ & $\begin{array}{l}\text { Cluster } 3 \\
\mathrm{n}=3\end{array}$ & PSD & $\begin{array}{l}p \text {-value } \\
\text { Levene }\end{array}$ & $\begin{array}{l}p \text {-value } \\
\text { Anova/Kruskall - Wallis }\end{array}$ \\
\hline Moisture (g $100 \mathrm{~g}^{-1}$ ) & 8.54 & 8.38 & 8.80 & 2.30 & 0.65 & 0.91 \\
\hline Protein $\left({\left.\mathrm{g} 100 \mathrm{~g}^{-1}\right)}^{-1}\right.$ & 3.82 & 3.60 & 3.87 & 0.37 & 0.89 & 0.38 \\
\hline Lipids (g $100 \mathrm{~g}^{-1}$ ) & 1.88 & 1.82 & 1.73 & 0.16 & 0.19 & 0.58 \\
\hline Total Reducing Sugars (g $100 \mathrm{~g}^{-1}$ ) & 37.71 & 37.93 & 37.64 & 0.36 & 0.11 & 0.46 \\
\hline Reducing Sugars $\left(\mathrm{g} 100 \mathrm{~g}^{-1}\right)$ & 26.80 & 26.81 & 26.73 & 0.34 & 0.47 & 0.93 \\
\hline Glucose $\left(\mathrm{g} 100 \mathrm{~g}^{-1}\right)$ & 7.00 & 7.11 & 7.18 & 0.59 & 0.92 & 0.80 \\
\hline Sucrose $\left({\left.\mathrm{g} 100 \mathrm{~g}^{-1}\right)}\right.$ & 10.91 & 11.12 & 10.91 & 0.38 & 0.75 & 0.64 \\
\hline Fructose $\left({\left.\mathrm{g} 100 \mathrm{~g}^{-1}\right)}^{1}\right.$ & 19.79 & 19.70 & 19.55 & 0.47 & 0.14 & 0.74 \\
\hline Dietary Fibre $\left(\mathrm{g} 100 \mathrm{~g}^{-1}\right)$ & 47.35 & 46.87 & 46.09 & 1.44 & 0.10 & 0.23 \\
\hline Pectin (g $\left.100 \mathrm{~g}^{-1}\right)$ & 13.29 & 13.40 & 12.77 & 1.24 & 0.56 & 0.51 \\
\hline Ash $\left(\mathrm{g} 100 \mathrm{~g}^{-1}\right)$ & $1.73^{\mathrm{a}}$ & $1.60^{\mathrm{b}}$ & $1.72^{\mathrm{ab}}$ & 0.10 & 0.69 & $<0.05^{*}$ \\
\hline Potassium (mg $100 \mathrm{~g}^{-1}$ ) & 233.71 & 232.29 & 235.19 & 7.05 & $<0.05$ & 0.60 \\
\hline Zinc (mg $100 \mathrm{~g}^{-1}$ ) & 1.09 & 0.95 & 0.92 & 0.20 & $<0.05$ & 0.53 \\
\hline Iron (mg $\left.100 \mathrm{~g}^{-1}\right)$ & 2.47 & 2.29 & 1.78 & 0.73 & 0.34 & 0.14 \\
\hline Calcium (mg $\left.100 \mathrm{~g}^{-1}\right)$ & $93.25^{\mathrm{b}}$ & $91.00^{\mathrm{b}}$ & $109.04^{\mathrm{a}}$ & 17.82 & $<0.001$ & $<0.05^{*}$ \\
\hline Manganese (mg $\left.100 \mathrm{~g}^{-1}\right)$ & 0.66 & 0.66 & 0.68 & 0.08 & 0.78 & 0.95 \\
\hline Magnesium (mg $100 \mathrm{~g}^{-1}$ ) & 79.10 & 79.47 & 80.58 & 10.88 & 0.07 & 0.95 \\
\hline
\end{tabular}

Note - PSD: pooled standard deviation; * significant at 95\% confidence; different letters in the same line indicate differences in the samples. 
study, the sample with a dose of $2 \mathrm{kGy}$ was stable throughout the study period; however, it had lower levels of potassium (Table 2).

There are few studies that analyse the behaviour of gamma radiation on minerals in foods and the stability of these minerals during storage. Hassan et al. (2013) studied the effect of gamma irradiation on the levels of calcium, phosphorus and iron in peanut at doses of 1.0, 1.5 and $2.0 \mathrm{kGy}$, and reported that there was a gradual increase in the levels of these minerals with increasing doses of radiation.

To provide a better understanding of the data set, to evaluate the interrelationships, and to verify the similarities between samples of apple pomace flour during storage, hierarchical cluster analysis (HCA) was applied to the physicochemical variables. The dendrogram in Fig. 1 shows the similarity between the samples that were
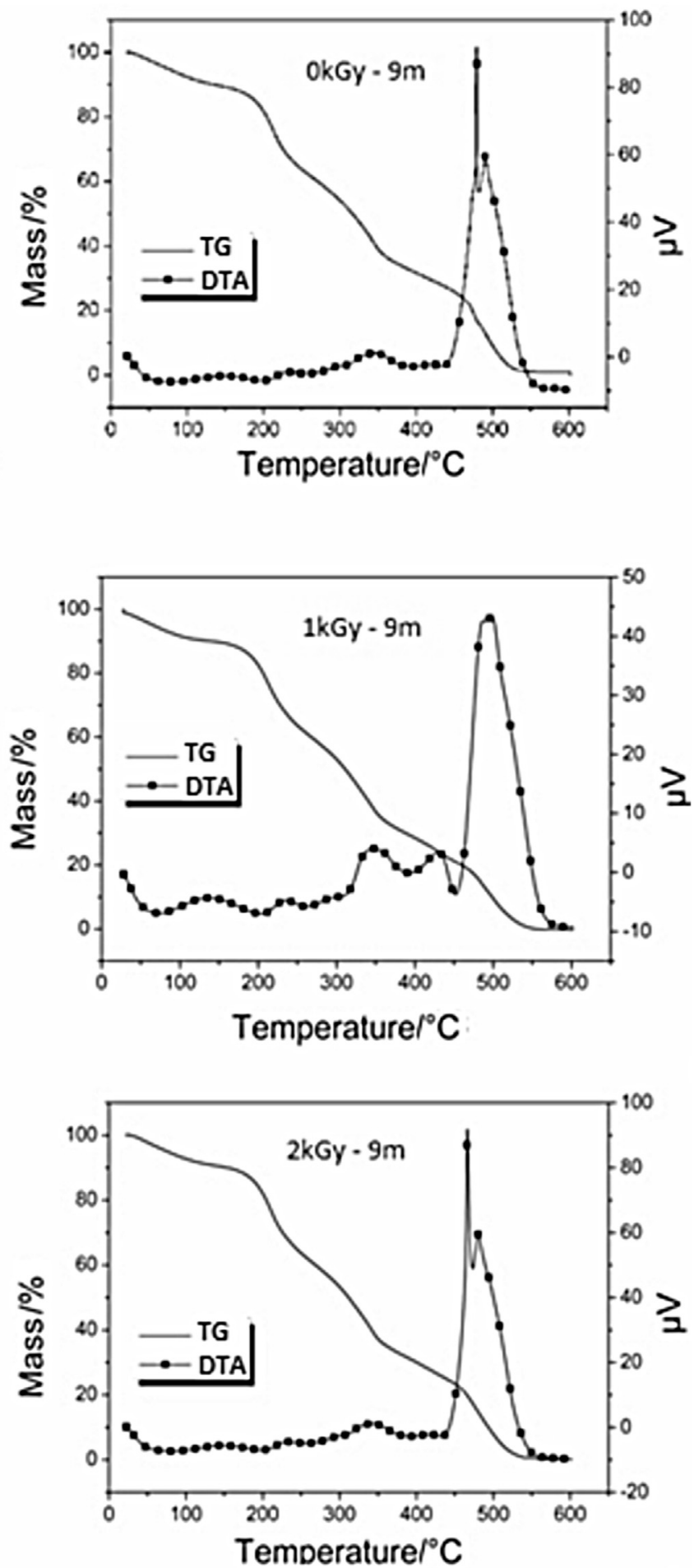

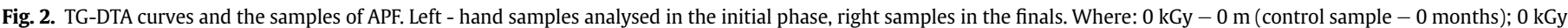

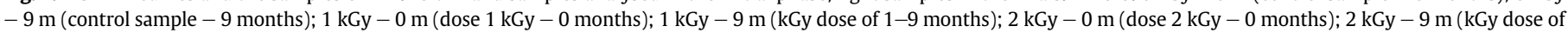
2-9 months). 
studied according to their physicochemical characteristics; three groups were suggested by HCA.

Table 3 shows that the means for each dependent variable were compared, and the ANOVA results for the clusters obtained by HCA were calculated. Only the ash and calcium variables had significant difference between clusters ( $\mathrm{p}<0.05$ ). Cluster 1 had higher values in the parameters of lipids, fructose, total dietary fibre, ash and zinc. Cluster 2 had higher levels of total reducing sugars, sucrose and pectin. Cluster 3 had the highest values for moisture, protein, glucose, potassium, calcium, manganese and magnesium. With the groups suggested by HCA, it is possible to confirm that the physicochemical parameters, in general, were not influenced by the effect of gamma radiation during storage.

\subsection{Effects of gamma radiation on thermal properties during storage}

The TG-DTA curves are shown in Fig. 2. The DTA curves overlapped the TG curves, facilitating the visualisation of thermogravimetric behaviour of the apple pomace flour. The TG curves showed a similar behaviour; the main weight loss occurred in four phases in consecutive reactions. Simultaneously, the DTA curves also showed the same behaviour, with two endothermic peaks and two exothermic peaks, except for the sample with radiation of $1 \mathrm{kGy}$ at 9 months, which presented five weight loss phases and one more exothermic peak, which was due to individual sample characteristics related to the heterogeneity of the raw material. All the data concerning weight loss range, temperature range, and the peak temperatures are shown in Table 4.

When analysing the samples in the initial phase of the study (TG-DTA left side of Fig. 2), the first weight loss (step 1), corresponding to the dehydration process, ranged between 3.64 ( $0 \mathrm{kGy}$ ), 2.25 ( $1 \mathrm{kGy}$ ) and 2.83 ( $2 \mathrm{kGy}$ ). By comparing these values with the final values at 9 months (TG/DTA on the right side of Fig. 2), which ranged between 10.36 ( $0 \mathrm{kGy}), 8.95$ ( $1 \mathrm{kGy}$ ) and 9.53 (2 kGy), it appears that this increased mass loss may be due to the fact that sample was hygroscopic and had also been stored for 9 months. Guerrero et al. (2014) reported that at temperatures below $200{ }^{\circ} \mathrm{C}$ a slight change in the sample conversion occurs, which was attributed to the removal of moisture that is adhered to the surface of the sample.

Decomposition started at $200{ }^{\circ} \mathrm{C}$ and the larger mass losses of the samples were between the temperatures of $200-450^{\circ} \mathrm{C}$ (Fig. 2). This can be attributed to the devolatilisation process. Analysing this behaviour, the weight loss that occurred at $200^{\circ} \mathrm{C}$ can be associated with the onset of the thermal degradation of lignin and hemicellulose (Munir, Daood, Nimmo, Cunliffe, \& Gibbs, 2009). The maximum devolatilisation of hemicellulose, cellulose and lignin occurs between 250 and $350{ }^{\circ} \mathrm{C}$. Cellulose decomposes between 277 and $427{ }^{\circ} \mathrm{C}$, hemicellulose around $197-327^{\circ} \mathrm{C}$ and lignin between 277 and $527^{\circ} \mathrm{C}$. It has been observed that the decomposition of apple pomace above a temperature of $450{ }^{\circ} \mathrm{C}$ proceeds more slowly, due to the decomposition of lignin (Guerrero et al., 2014).

All samples presented, at the end of the reaction, a large exothermic peak in the DTA curve, is related to the oxidation of organic matter (Leone, Colman, Schnitzler, Ellendersen, \& Masson, 2014). The final residue thermal decomposition (ash) levels of the apple pomace flour were $1.35 \%(0 \mathrm{kGy}-0 \mathrm{~m}), 1.41 \%(0 \mathrm{kGy}-9 \mathrm{~m})$, 0.74\% (1 kGy-0 m), 0.71 (1 kGy-9 m), 0.11 (2 kGy-0 m) and 0.09 (2 kGy-9 m) (Table 4).

\subsection{Effects of gamma radiation on microstructural properties during storage}

The photomicrographs are shown in Fig. 3 and one can observe an organic and heterogeneous material composition, with particle agglomerates which have irregular shapes and sizes that are characteristic of the samples. Some changes occurred, such as cracks, pores and smaller fragments in the apple pomace flour. In the control sample at time $0(A)$ the particles were larger, compared with the control sample, which was stored for nine months (B). The same situation occurred for the other stored samples; where irradiated with doses of 1 and $2 \mathrm{kGy}$ during storage (D and F) are agglomerated particles smaller fragments compared to the surveyed at time 0 ( $C$ and $E$ ). In the samples analysed at time 0 , it was observed that at doses of $1 \mathrm{kGy}(\mathrm{C})$ and $2 \mathrm{kGy}(\mathrm{E})$ there was an accumulation of smaller fragments, which resulted from cracks, pores and irregularities on the surface, compared to the control sample (A). The porosity of the feedstock was most apparent in the sample with a dose of $1 \mathrm{kGy}$ after 9 months of storage (D).

Some researchers have reported that the shape of starch granules and polysaccharides is deformed by gamma radiation (Byun et al., 2008; Choi, Kim, \& Lee, 2011; Choi, Kim, Kim, Kweon, \& Lee, 2010). Korotchenko and Sharpatyi (2004) observed that polysaccharides can degrade at higher doses of irradiation, leaving the structure amorphous, and this may increase crystallinity. A similar

Table 4

Results of TG-DTA curves for samples of APF.

\begin{tabular}{|c|c|c|c|c|c|}
\hline \multirow[t]{2}{*}{ Samples } & \multicolumn{2}{|c|}{ TG results } & \multicolumn{3}{|c|}{ DTA results } \\
\hline & Steps & $\Delta \mathrm{m}(\%)$ & $\Delta \mathrm{T}\left({ }^{\circ} \mathrm{C}\right)$ & $\mathrm{Tp}\left({ }^{\circ} \mathrm{C}\right)$ & Peak \\
\hline 0 kGy & 1 & 3.64 & $21-145$ & 77.30 & Endothermic \\
\hline \multirow[t]{3}{*}{0 months } & 2 & 33.80 & $\begin{array}{l}145 \\
-290\end{array}$ & 239.35 & Endothermic \\
\hline & 3 & 34.13 & $\begin{array}{l}290 \\
-404\end{array}$ & 344.28 & Exothermic \\
\hline & 4 & 27.08 & $\begin{array}{l}404 \\
-589\end{array}$ & 487.00 & Exothermic \\
\hline 0 kGy & 1 & 10.36 & $21-146$ & 62.59 & Endothermic \\
\hline \multirow[t]{3}{*}{9 months } & 2 & 27.64 & $\begin{array}{l}146 \\
-260\end{array}$ & 213.38 & Endothermic \\
\hline & 3 & 29.10 & $\begin{array}{l}260 \\
-391\end{array}$ & 342.32 & Exothermic \\
\hline & 4 & 31.49 & $\begin{array}{l}391 \\
-572\end{array}$ & 477.15 & Exothermic \\
\hline 1 kGy & 1 & 2.25 & $22-145$ & 62.01 & Endothermic \\
\hline \multirow[t]{3}{*}{0 months } & 2 & 34.02 & $\begin{array}{l}145 \\
-266\end{array}$ & 215.80 & Endothermic \\
\hline & 3 & 34.50 & $\begin{array}{l}266 \\
-410\end{array}$ & 350.00 & Exothermic \\
\hline & 4 & 28.48 & $\begin{array}{l}410 \\
-565\end{array}$ & 486.89 & Exothermic \\
\hline 1 kGy & 1 & 8.95 & $28-141$ & 59.1 & Endothermic \\
\hline \multirow[t]{4}{*}{9 months } & 2 & 30.53 & $\begin{array}{l}141 \\
-270\end{array}$ & 214.68 & Endothermic \\
\hline & 3 & 30.01 & $\begin{array}{l}270 \\
-393\end{array}$ & 342.76 & Exothermic \\
\hline & 4 & 8.37 & $\begin{array}{l}393 \\
-451\end{array}$ & 429.09 & Exothermic \\
\hline & 5 & 21.43 & $\begin{array}{l}451 \\
-591\end{array}$ & 482.31 & $\begin{array}{l}\text { Exothermic } \\
\text { Exothermic }\end{array}$ \\
\hline 2 kGy & 1 & 2.83 & $24-150$ & 77.35 & Endothermic \\
\hline \multirow[t]{3}{*}{0 months } & 2 & 33.21 & $\begin{array}{l}150 \\
-285\end{array}$ & 240.00 & Endothermic \\
\hline & 3 & 36.91 & $\begin{array}{l}285 \\
-400\end{array}$ & 361.09 & Exothermic \\
\hline & 4 & 26.94 & $\begin{array}{l}400 \\
-580\end{array}$ & 485.91 & Exothermic \\
\hline 2 kGy & 1 & 9.53 & $22-140$ & 45.68 & Endothermic \\
\hline \multirow[t]{3}{*}{9 months } & 2 & 31.05 & $\begin{array}{l}140 \\
-271\end{array}$ & 209.95 & Endothermic \\
\hline & 3 & 33.53 & $\begin{array}{l}271 \\
-431\end{array}$ & 339.81 & Exothermic \\
\hline & 4 & 25.77 & $\begin{array}{l}431 \\
-580\end{array}$ & 482.77 & Exothermic \\
\hline
\end{tabular}

$\Delta \mathrm{m}$ - mass loss; $\Delta \mathrm{T}$ - temperature variation; $\mathrm{Tp}$ - peak temperature. 
result was found in a study of irradiated chitosan by Ulański and Rosiak (1992), which found that degradation resulted in smaller structures due to breaking of the polymer chains; this is due to the radical $\beta$-cleavage, which can lead to opening of the anhydroglucose ring or breaks in the glycosidic bond.

Prakash, Guner, Caporaso, and Foley (2000) reported that irradiation can cause changes in the cellulose and pectin present in the cell walls of plant tissues, resulting in discolouration and softening of tissues. In contrast, Heredia-Guerrero et al. (2012) studied the effect of low doses of gamma radiation on tomato cuticles using scanning electron microscopy and found that irradiation caused some textural changes on the surface, but no significant chemical modifications in the fruit.

\subsection{Effects of gamma radiation on microbiological properties during storage}

As can be seen in Table 5, there was no growth of thermotolerant coliforms and Salmonella sp., in the samples during storage. Values of these bacteria that were non-detectable, or below those permitted by law, were also observed in apple pomace flour by (Coelho \& Wosiacki, 2010). Regarding the analyses of moulds and yeasts in the first stage (time 0 ) was found in the sample mould control $(0 \mathrm{kGy})$, however, below which calls for legislation. In the last stage (9 months), the growth of filamentous fungi was observed in the samples $0 \mathrm{kGy}$ and $1 \mathrm{kGy} 1.37 \times 10^{5} \mathrm{CFU} \mathrm{g}{ }^{-1}$ and $3.7 \times 10^{3} \mathrm{CFU} \mathrm{g}^{-1}$, respectively. The value found for the $0 \mathrm{kGy}$ sample was greater than the tolerance for the sample, which was indicative of $10^{4} \mathrm{CFU} \mathrm{g}{ }^{-1}$. At a dose of $1 \mathrm{kGy}$, the value was below the indicative tolerance (ANVISA, 2001).

This presence of moulds may be related to the storage time of the apple pomace flour where there was an increase in the moisture and water activity $\left(A_{w}\right)$. The initial $A_{w}(0$ months) was 0.27 for the control sample, 0.26 for the sample with a dose of $1 \mathrm{kGy}$ and 0.24 for the sample with a dose of $2 \mathrm{kGy}$. The final $\mathrm{A}_{\mathrm{w}}$ (9 months) was 0.45 for the control sample, 0.43 for the sample with a dose of $1 \mathrm{kGy}$, and 0.42 for the sample with a dose of $2 \mathrm{kGy}$. In the irradiated sample with a dose of $2 \mathrm{kGy}$ there was no contamination by fungi. In addition to the mould count we also identified two filamentous fungal genera (Penicillium and Cladosporium), both of which were present in the sample with $0 \mathrm{kGy}$ (control sample) that was analysed in the last step ( 9 months).

These results indicate that gamma irradiation can be effective for inhibiting of microorganisms, as noted by Ahari Mostafavi, Mahyar Mirmajlessi, Fathollahi, Shahbazi, and Mohammad Mirjalili (2013) where determined that a dose of 600 Gy was efficacy to achieve the complete inhibition of Penicillium expansum.

Penicillium grows in organic soil matter, in damp and dark
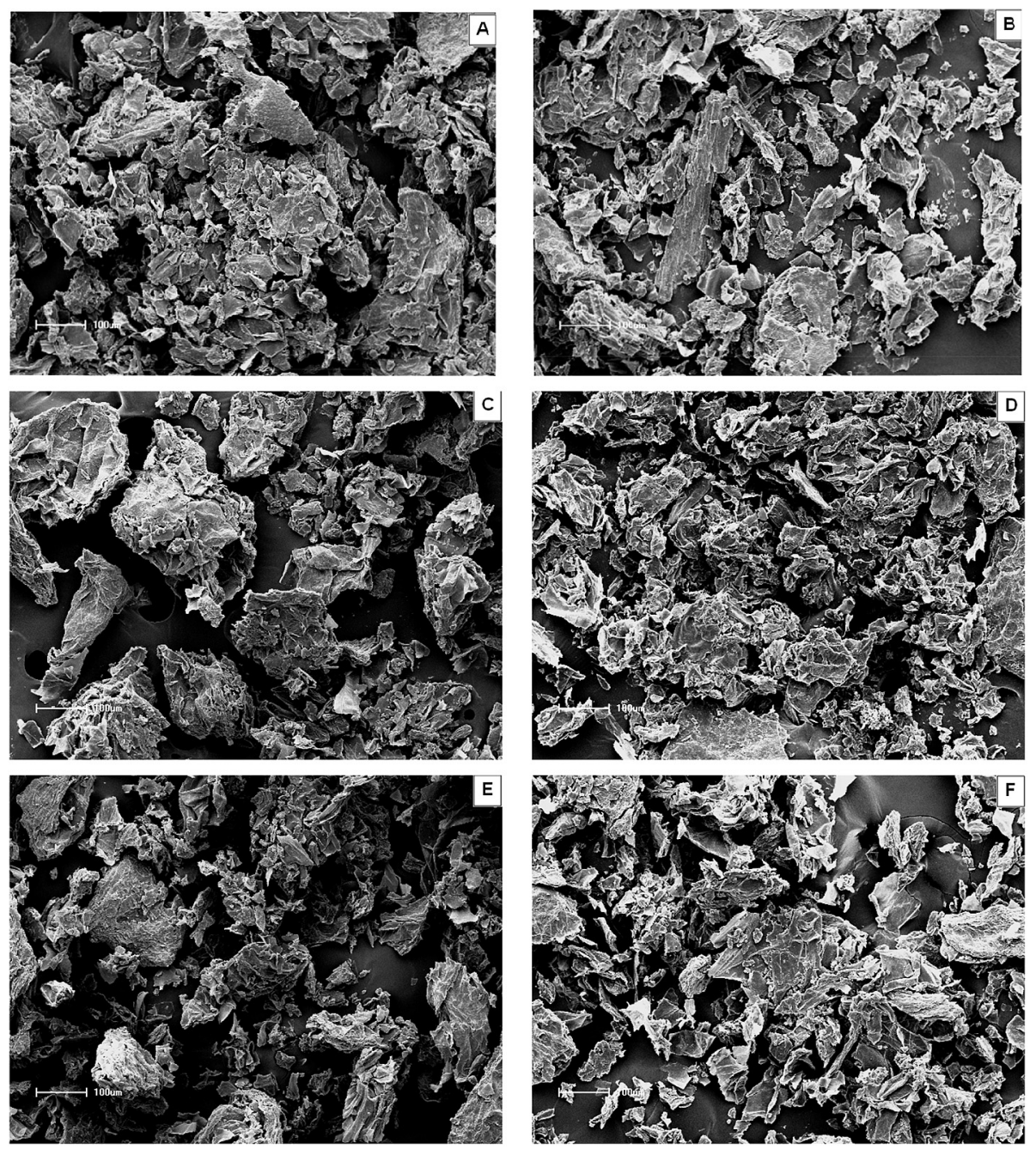

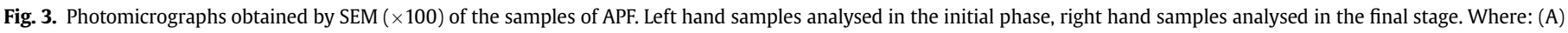
control sample - $0 \mathrm{~m}$; (B) control sample - 9 months; (C) dose $1 \mathrm{kGy}-0 \mathrm{~m}$; (D) dose of $1 \mathrm{kGy}-9$ months; (E) dose $2 \mathrm{kGy}-0 \mathrm{~m}$; (F) dose of $2 \mathrm{kGy}-9 \mathrm{months}$. 
Table 5

Results of microbiological analyses for samples of apple pomace flour during storage.

\begin{tabular}{|c|c|c|c|c|}
\hline Doses (kGy) & Time (months) & $\begin{array}{l}\text { Thermotolerant coliforms } \\
\mathrm{NMP} / \mathrm{g}\end{array}$ & $\begin{array}{l}\text { Salmonella sp } \\
25 \mathrm{~g}\end{array}$ & $\begin{array}{l}\text { Moulds and yeasts } \\
\text { UFC/g }\end{array}$ \\
\hline \multirow[t]{2}{*}{0} & 0 & ND & ND & $<10^{2}$ \\
\hline & 9 & ND & ND & $1.37 \times 10^{5}$ \\
\hline \multirow[t]{2}{*}{1} & 0 & ND & ND & $<10^{2}$ \\
\hline & 9 & ND & ND & $3.7 \times 10^{3}$ \\
\hline \multirow[t]{2}{*}{2} & 0 & ND & ND & ND \\
\hline & 9 & ND & ND & ND \\
\hline
\end{tabular}

$\mathrm{ND}=$ not detected

environments. By contagion, it contaminates fruit and seeds and is responsible for the moulds that settle in food that is used for human consumption. According to Li et al. (2015), Penicillium expansum, which causes blue mould, is a major contributor to the losses caused by rot in various apple producing regions. The greatest damage caused by this fungus does not relate to the fungus itself, but to a mycotoxin, patulin. This is the major contaminant in apples and their derivatives, and it can cause acute toxic effects in humans.

Cladosporium has dark brown or black spots; it has a velvety aspect and can form branches. It attacks plants, causing serious damage and large losses, especially for agriculture. The Cladosporium herbarum, which is associated with carpel rot in apples, is a disease that is characterised by the formation of black or grey coloured micelles, which damage fruit. Infection occurs through parts of the flower and the disease can also develop in orchards (Shenderey et al., 2010).

\section{Conclusion}

The evaluation of gamma - radioisotope ${ }^{60} \mathrm{Co}$, in apple pomace flour during prolonged storage was investigated for the first time in relation to physicochemical, thermogravimetric, microstructure and microbiological properties. The chemometric approach proved to be effective in facilitating the visualisation of the physicochemical parameters of the samples. With the clusters that were suggested by HCA, in general, it can be stated that the results were not influenced by the effect of gamma radiation during storage.

For the microbiological analysis at a dose of $1 \mathrm{kGy}$, the presence of yeasts and moulds occurred at 9 months of storage; however, the levels were below the indicative tolerance. It is important to stand out that irradiated sample with a dose of $2 \mathrm{kGy}$ there was no contamination of yeasts and moulds.

The mineral calcium had higher levels in the irradiated samples and over longer storage times these values increased. The irradiated apple pomace flour that was stored for nine months showed stable contents of protein, lipids, total dietary fibre, total reducing sugars, potassium, zinc, iron and manganese and a good source of fibre. It can be applied to products with high added value, aimed at economy and reducing the environmental impact. Therefore, gamma irradiation can be used as an alternative processing technique to preserve the physicochemical and microbiological parameters in the apple pomace flour.

\section{Acknowledgements}

The authors are deeply grateful to the National Council of Araucaria Foundation (FA), Coordination for the Improvement of Personnel in Higher Level (CAPES) for the scholarships (CAPES/ PNPD - A. A. F. Zielinski) offered during the implementation period of this research and C-LABMU-UEPG for the infrastructure. The authors, especially dedicate this research to the memory of one most distinguished researcher, dedicated his life to Science,
Professor Dr. Gilvan Wosiacki (in memorian). He passed away in 2015 and will remain with us as a source of inspiration forever.

\section{References}

Ahari Mostafavi, H., Mahyar Mirmajlessi, S., Fathollahi, H., Shahbazi, S., \& Mohammad Mirjalili, S. (2013). Integrated effect of gamma radiation and biocontro agent on quality parameters of apple fruit: An innovative commercial preservation method. Radiation Physics and Chemistry, 91(0), 193-199.

Alberti, A., Machado dos Santos, T. P., Ferreira Zielinski, A. A., Eleutério dos Santos, C. M., Braga, C. M., Demiate, I. M., et al. (2016). Impact on chemical profile in apple juice and cider made from unripe, ripe and senescent dessert varieties. LWT - Food Science and Technology, 65, 436-443.

ANVISA. (2001). Resolução RDC n¹2. Brasilia: Diário Oficial da União, 2001 (02.01.2001).

AOAC. (2005). AOAC - official methods of analysis (18th ed.). Washington, DC, USA: Association of Official Analytical Chemist.

Byun, E. H., Kim, J. H., Sung, N. Y., Choi, J., Lim, S. T., Kim, K. H., et al. (2008). Effects of gamma irradiation on the physical and structural properties of $\beta$-glucan. Radiation Physics and Chemistry, 77(6), 781-786.

Choi, J. i., Kim, J. K., Kim, J. H., Kweon, D. K., \& Lee, J. W. (2010). Degradation of hyaluronic acid powder by electron beam irradiation, gamma ray irradiation, microwave irradiation and thermal treatment: A comparative study. Carbohydrate Polymers, 79(4), 1080-1085.

Choi, J. i., Kim, H. J., \& Lee, J. W. (2011). Structural feature and antioxidant activity of low molecular weight laminarin degraded by gamma irradiation. Food Chemistry, 129(2), 520-523.

Coelho, L. M., \& Wosiacki, G. (2010). Avaliação sensorial de produtos panificados com adição de farinha de bagaço de maçã. Food Science and Technology (Campinas), 30, 582-588.

Dhillon, G. S., Kaur, S., Brar, S. K., \& Verma, M. (2012). Potential of apple pomace as a solid substrate for fungal cellulase and hemicellulase bioproduction through solid-state fermentation. Industrial Crops and Products, 38(0), 6-13.

FAO. (2015). Food and agricultural organization. http://www.fao.org (Accessed 6 June 2015).

Fertonani, H. C. R., Scabio, A., Carneiro, E. B. B., Schemim, M. H. C., Nogueira, A., \& Wosiacki, G. (2009). Extraction model of low methoxyl pectin from apple pomace effects of acid concentration and time on the process and the product. Brazilian Archives of Biology and Technology, 52, 177-185.

Guerrero, M. R. B., Marques, S. P. M., Zaragoza, M. M., Gutiérrez, J. S. Velderrain, V. G., Ortiz, A. L., et al. (2014). Thermogravimetric study on the pyrolysis kinetics of apple pomace as waste biomass. International Journal of Hydrogen Energy, 39(29), 16619-16627.

Hassan, A. B., Diab, E. E., Mahmoud, N. S., Elagib, R. A. A., Rushdi, M. A. H., \& Osman, G. A. M. (2013). Effect of radiation processing on in vitro protein digestibility and availability of calcium, phosphorus and iron of peanut. Radiation Physics and Chemistry, 91(0), 200-202.

Heredia-Guerrero, J. A., de Lara, R., Domínguez, E., Heredia, A., Benavente, J., \& Benítez, J. J. (2012). Chemical-physical characterization of isolated plant cuticles subjected to low-dose $\gamma$-irradiation. Chemistry and Physics of Lipids, 165(8), 803-808.

Hunsche, M., Brackmann, A., \& Ernani, P. R. (2003). Effect of potassium fertilization on the postharvest quality of 'Fuji' apples. Pesquisa Agropecuaria Brasileira, 38(4), 489-496.

IAEA. (2015). International Atomic Energy Agency. http://www.iaea.org (Accessed 6 June 2015).

Ito, V. C., Alberti, A., Avila, S., Spoto, M., Nogueira, A., \& Wosiacki, G. (2016). Effects of gamma radiation on the phenolic compounds and in vitro antioxidant activity of apple pomace flour during storage using multivariate statistical techniques. Innovative Food Science \& Emerging Technologies, 33, 251-259.

Ito, V. C., Avila, S., \& Wosiacki, G. (2015). Apple Pomace: Either residue or raw material, some cute applications. Fruit Processing, 25(6), 248-251.

Korotchenko, K. A., \& Sharpatyi, V. A. (2004). Radiation chemistry of polysaccharides: 3 . On the strange dose dependence of the buildup of some radiolysis products. High Energy Chemistry, 38(4), 231-235.

Kosmala, M., Kolodziejczyk, K., Zduńczyk, Z., Juśkiewicz, J., \& Boros, D. (2011). Chemical composition of natural and polyphenol-free apple pomace and the 
effect of this dietary ingredient on intestinal fermentation and serum lipid parameters in rats. Journal of Agricultural and Food Chemistry, 59(17), 9177-9185.

Leone, R. d. S., Colman, T. A. D., Schnitzler, E., Ellendersen, L. N., \& Masson, M. L. (2014). Evolved gas analysis (coupled TG-DSC-FTIR) applied to the therma behaviour of inulin. Journal of Analytical and Applied Pyrolysis, 108(0), 323-326.

Li, H., Wang, Y., Liu, F., Yang, Y., Wu, Z., Cai, H., et al. (2015). Effects of chitosan on control of postharvest blue mold decay of apple fruit and the possible mechanisms involved. Scientia Horticulturae, 186(0), 77-83.

Munir, S., Daood, S. S., Nimmo, W., Cunliffe, A. M., \& Gibbs, B. M. (2009). Therma analysis and devolatilization kinetics of cotton stalk, sugar cane bagasse and shea meal under nitrogen and air atmospheres. Bioresource Technology, 100(3) $1413-1418$.

Oliveira, M. C. S., Silva, N. C. C., Nogueira, A., \& Wosiacki, G. (2006). Avaliação do método de liquefação enzimática na extração de suco de maçã/Evaluation of apple juice extraction by the enzyme liquefaction method. Ciência e Tecnologia de Alimentos, 26(4), 906

Pereira, C., Calhelha, R. C., Antonio, A. L., Queiroz, M. J. R. P., Barros, L., \& Ferreira, I. C. F. R. (2014). Effects of gamma radiation on chemical and antioxidant properties, anti-hepatocellular carcinoma activity and hepatotoxicity of borututu. Innovative Food Science \& Emerging Technologies, 26(0), 271-277.

Pirmohammadi, R., Rouzbehan, Y., Rezayazdi, K., \& Zahedifar, M. (2006). Chemica composition, digestibility and in situ degradability of dried and ensiled apple pomace and maize silage. Small Ruminant Research, 66(1-3), 150-155.

Prakash, A., Guner, A. R., Caporaso, F., \& Foley, D. M. (2000). Effects of low-dose gamma irradiation on the shelf life and quality characteristics of cut romaine lettuce packaged under modified atmosphere. Journal of Food Science, 65(3), $549-553$.

Shenderey, C., Shmulevich, I., Alchanatis, V., Egozi, H., Hoffman, A., Ostrovsky, V., et al. (2010). NIRS detection of moldy core in apples. Food and Bioprocess Technology, 3(1), 79-86.

Somogyi, M. (1952). Notes on sugar determination. Journal of Biological Chemistry, $19-23$.

Tawema, P., Han, J., Vu, K. D., Salmieri, S., \& Lacroix, M. (2016). Antimicrobial effects of combined UV-C or gamma radiation with natural antimicrobial formulations against Listeria monocytogenes, Escherichia coli 0157: H7, and total yeasts/ molds in fresh cut cauliflower. LWT - Food Science and Technology, 65, 451-456.

Ulański, P., \& Rosiak, J. (1992). Preliminary studies on radiation-induced changes in chitosan. International Journal of Radiation Applications and Instrumentation. Part C. Radiation Physics and Chemistry, 39(1), 53-57.

USDA. (2015). Economics, statistics and market information system (ESMIS). http:// www.usda.mannlibcornell.edu (Accessed 1 July 2015).

WHO. (2015). World Health Organization. http://www.who.int (Accessed 6 June 2015).

Yan, H., \& Kerr, W. L. (2013). Total phenolics content, anthocyanins, and dietary fibre content of apple pomace powders produced by vacuum-belt drying. Journal of the Science of Food and Agriculture, 93(6), 1499-1504.

Zielinski, A., Haminiuk, C., Alberti, A., Nogueira, A., Demiate, I., \& Granato, D. (2014). A comparative study of the phenolic compounds and the in vitro antioxidant activity of different Brazilian teas using multivariate statistical techniques. Food Research International, 60(0), 246-254. 